\title{
Pengaruh Corporate Governance dan Pengungkapan Corporate Social Responsibility Terhadap Agresivitas Pajak
}

\author{
RR. Maria Yulia Dwi Rengganis ${ }^{1}$ \\ I.G.A.M Asri Dwija Putri
}

\author{
${ }^{1}$ Fakultas Ekonomi dan Bisnis Universitas Udayana (Unud), Bali, Indonesia \\ email: dwiyuliaa67@gmail.com / telp: +6289512478401 \\ ${ }^{2}$ Fakultas Ekonomi dan Bisnis Universitas Udayana (Unud), Bali, Indonesia
}

\begin{abstract}
ABSTRAK
Agresivitas pajak adalah sebuah langkah yang ditempuh perusahaan sebagai strategi untuk meminimalkan beban pajak yang semestinya dibayar.Nilai ETR dalam penelitian ini digunakan untuk memproksikan variabel agresivitas pajak. Rendahnya nilai ETR suatu perusahaan menggambarkan tindak agresivitas pajak pada perusahaan itu semakin tinggi. Tujuan dilakukannya penelitian ini bertujuan untuk mengetahui pengaruh Corporate Governance dan Pengungkapan CSRterhadap Agresivitas Pajak menggunakan proksi ETR. Seluruh perusahaan manufaktur yang terdaftar di BEI tahun 2013-2015 merupakan populasi penelitian ini.Perusahaan yang terpilih menjadi sampel setelah dikurangi beberapa kriteria adalah sebanyak 99 perusahaan amatan.Hasil pengujian memberikan bukti adanya pengaruhpengungkapan CSR pada ETR sebagai proksi dari agresivitas pajak.Perusahaan dengan tingkat pengungkapan CSR yang semakin tinggi,nilai ETRnya juga meningkat, yang menggambarkan semakin rendahnya tingkat agresivitas pajak yang dilakukan perusahaan.
\end{abstract}

Kata Kunci: Agresivitas Pajak,Corporate Governance, Corporate Social Responsibility

\begin{abstract}
The tax aggressiveness is step of company as strategy minimizethe tax that must paid. This research uses ETR as proxy of the tax aggressiveness. The lower value of ETR of company depicts the high aggressiveness tax those companies. This research has a purpose to giving information about the impact of Corporate Governance and Disclosure of Corporate Social Responsibility On the Aggressiveness Tax representative with ETR. All of manufacturing companies listed on Indonesian stocks Exchanges on 2013-2015 is the population of this research. Companies selected into the sample after deducting some of the criteria is as much99 of the company observations. This study has results that prove the disclosure ofCSR affect the ETR as proxy of tax aggressiveness. Value of CSR disclosure company high, so value of ETR is higher which describe the lower aggressiveness tax of the companies.
\end{abstract}

Keywords: Tax Aggressiveness, Corporate Governance, Corporate Social Responsibility

\section{PENDAHULUAN}

Pajak adalah sumber utama penerimaan Negara, sebagai sumber pembiayaan untuk kegiatan pembangunan nasional dalam upaya mewujudkan kesejahteraan masyarakat. Setiap tahunnya pemerintah selalu meningkatkan target penerimaan 
RR. Maria Yulia Dwi Rengganis dan I.G.A.M Asri Dwija Putri. Pengaruh ....

pajak, namun pada kenyataannya penerimaan pajak yang ditargetkan oleh pemerintah tidak tercapai.

Tabel 1.

Penerimaan Pajak Tahun 2011-2015

\begin{tabular}{|c|c|c|c|}
\hline Tahun & $\begin{array}{c}\text { Target (Dalam } \\
\text { Triliun Rupiah) }\end{array}$ & $\begin{array}{l}\text { Realisasi (Dalam } \\
\text { Triliun Rupiah) }\end{array}$ & $\begin{array}{c}\text { \% tase Realisasi } \\
\text { Penerimaan Pajak }\end{array}$ \\
\hline 2011 & 878,70 & 873,90 & $99,45 \%$ \\
\hline 2012 & $1.032,57$ & 980,50 & $94,96 \%$ \\
\hline 2013 & $1.148,40$ & $1.077,30$ & $93,81 \%$ \\
\hline 2014 & $1.246,10$ & $1.146,90$ & $92,04 \%$ \\
\hline 2015 & $1.294,25$ & $1.055,00$ & $81,51 \%$ \\
\hline
\end{tabular}

Berdasarkan data Kementerian Keuangan Republik Indonesia pada Tabel 1. besarnya realisasi penerimaan Negara dari sektor pajak yang meliputi semua jenis pajak pada tahun 2011 adalah sebesar873,90Triliun Rupiah dari jumlah penerimaan yangditargetkan yaitu 878,70 Triliun Rupiah. Dengan tercapainya penerimaan pajak sebesar itu maka bila dipersentasekan penerimaan pajaknya adalah sebesar 99,45\%dari jumlah target.

Tahun 2012 penerimaan pajaknya sebesar 980,50 Triliun Rupiah darijumlah penerimaan yang ditargetkanyaitu 1.032,57TriliunRupiah.Dengan tercapainya penerimaan pajak sebesar itu maka bila dipersentasekan penerimaan pajaknya adalah sebesar94,96\%dari jumlah target.Tahun 2013 pencapaian realisasi penerimaan pajaknya adalah sebesar 1.077,30 Triliun Rupiah dari jumlah penerimaan yang ditargetkanyaitu 1.148,40 Triliun Rupiah. Dengan tercapainya penerimaan pajak sebesar itu maka bila dipersentasekan penerimaan pajaknya adalah sebesar93,81\%dari jumlah target yang ingin dicapai. 
Tahun 2014 realisasi penerimaan pajak adalah sebesar1.146,90 Triliun Rupiah darijumlah penerimaan yang ditargetkansebesar 1.246,10 Triliun Rupiah. Dengan tercapainya penerimaan pajak sebesar itu maka bila dipersentasekan penerimaan pajaknya adalah sebesar92,04\%. Terakhir pada tahun 2015 tercatat penerimaan pajak mencapai angka $1.055,00$ Triliun Rupiah dari jumlah penerimaan yang ditargetkansebesar 1.294,25 Triliun Rupiah.Jumlah tersebut mencapai $81,51 \%$.

Tidak tercapainya target penerimaan pajak tersebut salah satunya disebabkan karena wajib pajak (WP) dapat melakukan suatu perencanaan pajak sebagai usaha dalam mencapai efisiensi beban pajak. Wajib Pajak dapat melakukan suatu perencanaan pajak karena Indonesia menerapkan Self Assessment systemsebagai sistem perpajakannya,dimana sistem ini adalah sebuah sistem perpajakan yang memberi wewenang serta kepercayaan pada WP untuk menghitung, membayar dan melaporkan pajak terhutangnya secara mandiri. UpayaWP untuk menurunkan beban pajaknya menggambarkan tingkat agresivitas pajak yang dilakukannya.

Perusahaan sebagai wajib pajakbadan berkewajibanuntuk membayarkan pajak berdasarkan laba bersih.Perusahaan menganggap pajak sebagai bebanperusahaanyang bisa mengurangi laba. Hal tersebut mendorong perusahaan mengambil langkah untuk meminimalkan besaran pajak yang ditanggungnya, sehingga perusahaan cenderung dipandang telah melakukan tindakan agresivitas pajak. 
RR. Maria Yulia Dwi Rengganis dan I.G.A.M Asri Dwija Putri. Pengaruh ....

Frank et al. (2009) menyatakan bahwasegala upaya atau usaha yang dilakukan perusahaandalam melakukanperekayasaanbesarnya penghasilan kena pajak dengan membuat suatuperencanaan pajak, dengancara yangdikategorikanlegal ataupunillegaldisebut dengan agresivitas pajak.Perusahaan yang teridentifikasi memiliki kecenderungan agresifterhadap pajak identik akan rendahnya tingkat transparansi pada perusahaan (Balakrishnan et al., 2011).Bukti-bukti empirisyang diperoleh memperlihatkanadanya indikasi tingginya tingkat agresivitas pajak dikarenakan lemahnya tata kelola perusahaan (Jimenez, 2008).

Effective Tax Rate (ETR) digunakan dalam penelitian ini untuk memproksikan variabel agresivitas pajak.Wibowo (2012) dalam Hanum dan Zulaikha (2013) mendefinisikan ETR sebagai suatu rasio pajak yang dibayarsuatu perusahaan atasjumlah penghasilan sebelum pajak, dengan demikian bisadiketahui besarnya prosentase perubahan pembayaran pajak sesungguhnya terhadap laba komersial yang diterima perusahaan.

Karayan dan Swenson (2007) mengungkapkan ada banyak cara yang digunakan untuk menilaibagaimana perusahaan mengatur beban pajaknya, salah satunya adalah dengan mengamati besaran tarif efektifnya.Rendahnya nilai ETR perusahaan menggambarkan bahwa beban pajak penghasilan perusahaan lebih kecil dari penghasilan sebelum pajaknyayang menunjukkanadanya kemungkinan tindak agresivitas pajak yang cukup tinggi. Hal tersebut karena ada kemungkinan perusahaan tersebut tidak membayarkan beban pajak dalam jumlah yang 
semestinya. Nilai ETR perusahaan yang semakin rendah mengindikasikansemakin tingginya tingkatagresivitas pajak perusahan tersebut.

Tindakan agresivitas pajak merupakan tindakan yang bertentangan dengan keinginan dan harapan dari lingkungan masyarakat. Apabila perusahaan terbukti melakukan suatu tindakan agresivitas pajak akan memperoleh pandangan negatif dari masyarakat karena dirasa kurang memiliki tanggung jawab sosial. Perusahaan sebagai organisasi yang sangat berkaitan dengan masyarakat dan lingkungan tentunya tidak menginginkan mendapat pandangan negatif dari masyarakat. Salah satu upaya mengendalikan tindakan agresivitas pajak adalah dengan cara melaksanakan corporate governance sehingga dapat mengawasipengelolaan perusahaan oleh manajemen, termasuk dalam hal kebijakan perpajakan perusahaan.

Aturan struktur Corporate governace pada perusahaan dapat menentukan pembuatan kebijakan termasuk dalam hal kebijakan perpajakan, namun di lain sisi tindakan pengelolaan pajak bergantung kepada mekanisme berjalannya corporate governance diperusahaan. Terdapat lima prinsip pokok GCG yang harus dijalankan oleh perusahaan yaitu transparansi, akuntabilitas, responsibilitas, independensi serta kewajaran. Prinsip transparansi diterapkan pada perusahaan agar objektivitas bisnis yang dijalankan tetap terjaga. Untuk menerapkan prisnsip transparansi setiap perusahaan harus menyediakan seluruh informasi secara relevan serta harus dipastikan bahwa informasi dapat dengan mudah diakses serta dimengerti oleh setiap pihak yang berkepentingan. Bukansaja masalah yang diatur oleh ketentuan yang harus disediakan oleh perusahaan, namun perusahaan sudah 
RR. Maria Yulia Dwi Rengganis dan I.G.A.M Asri Dwija Putri. Pengaruh ....

seharusnya berinisiatifuntuk menyediakan serta mengungkapkan hal-hal penting yang dibutuhkan oleh seluruh pemangku kepentingan yang berguna dalam pengambilan keputusan perusahaan.

Prinsip kedua yaitu prinsip akuntabilitas, dimana prinsip ini menunjukkan bahwaPerusahaan seharusnya dikelola secara baik dan benar sesuai dengan kepentingan perusahaan dengan tidak mengabaikan kepentingan pemegang saham maupun para pemangku kepentingan lainnya, dan tentunya harus sesuai dengan peraturan yang berlaku. Selain itu, perusahaan juga semestinya bisa mempertanggungjawabkan kinerjanya secara wajar serta transparan.Untuk mencapai suatu kinerja yang berkesinambungan prinsip akuntabilitas merupakan syarat penting yang harus diterapkan dalam perusahaan.

Prinsip ketiga adalah prinsip responsibilitas. Prinsip ini mengharuskan perusahaan menaati peraturanyang ada serta menjalankan tanggungjawabnya kepada lingkungan dan masyarakat agaroperasional perusahaan dapat terjaga dalam jangka waktu yangpanjang sehingga mendapat pengakuan yang baik dari masyarakat. Prinsip keempat yang harus dijalankan oleh perusahaan adalah prinsip independensi. Prinsip ini mengharuskan perusahaan dikelola secara independen agar tidak ada pihak yang bertindak dominan dalam perusahaan dan agar tidak terjadi intervensi oleh pihak lain. Prinsip kelima yaitu prinsip kewajaran. Prinsip ini menegaskan bahwa perusahaan dalam menjalankan setiap kegiatan harus selalu memperhatikan kepentingan seluruh pemangku kepentingan perusahaan berdasarkan asas kewajaran dan kesetaraan. 
Apabila dalam sebuah perusahaan mekanisme Corporate governace dapat terlaksana dengan baik, maka akan berpengaruh juga terhadap meningkatnya nilai tambah bagi para pemegang saham.Untuk memahami konsep corporate governance teori yang tepat untuk digunakan adalah teori agensi.Berdasarkan teori ini, tata kelola suatu perusahaan harus diawasiserta di kendalikan guna memberikan keyakinan bahwa tata kelola perusahaan sudah dijalankan dengan mengacu pada kepatuhan peraturan dan ketentuan yang berlaku.

Beberapa penelitian terdahulu tentang hubungan antara corporate governance dengan agresivitas pajak perusahaan dilakukan oleh Sartori (2010), Putranti dan Setiawanta (2015). Sartori (2010)mengungkapkan bahwa tata kelola perusahaan berpengaruh positif untuk meningkatkan ketaatan pajak perusahaan, sehingga dapat meminimalkan tingkat agresivitas pajak. Selain itu, Putranti dan Setiawanta (2015) mengungkapkanadabeberapa variabel independen dalam penelitiannya yang berpengaruh terhadap tingkattax avoidance perusahaan yaitu variabel kepemilikan institusional yang berarah negatif, variabel kualitas audit berarah positif, dan jumlah dewan komisaris yang berarah positif sedangkan variabel yang tidak ada pengaruhnyapada kebijakan tax avoidanceadalah variabel komisaris independen serta variabel komite audit.

Variabel corporate governance diukur dengan 3 proksi yaitu komisaris independen, ukuran dewan direksi, dan komite audit. Dalam proses pengambilan keputusan di sebuah perusahaan dibutuhkan penyeimbang yang berfungsi untuk melindungi setiap kepentingan dan hak-hak yang dimiliki oleh pemegang saham minoritas serta seluruh pihak lain yang terkait. Bursa Efek Indonesia (BEI) 
RR. Maria Yulia Dwi Rengganis dan I.G.A.M Asri Dwija Putri. Pengaruh ....

memiliki suatuperaturan dimana dalam perusahaan diharuskan terdapat minimal $30 \%$ dewan komisaris independen, sehingga pengawasan dapat berjalan dengan baik (Pohan, 2008).Dengan adanya komisaris independen didalam keanggotaan dewan direksi, pengawasan kinerja direksi perusahaan dapat ditingkatkan. Dewan direksi memegang suatu peranan penting dalam mekanisme corporate governance dikarenakan tanggung jawab atas segala urusan dan kepentingan perusahaan diserahkan oleh hukum perseroan kepada dewan direksi.

Laporan keuangan perusahaan seharusnya dibuat sesuai GAAP serta disajikan secara wajar, dalam perusahaan yang diberikan tanggungjawab untuk memastikan hal tersebut sudah terlaksana adalah komite audit. Prinsip transparansi harus diperhatikan dalam memberi atau mengungkap informasiinformasi yang material dan relevan mengenai perusahaan. Selain prinsip transparansi, prinsip lain yang diperhatikan dan dilaksanakan oleh komite audit adalah akuntabilitas dan responsibilitaskarena tugas dan fungsi komite audit telah dilaksanakan sesuai dengan prinsip-prinsip korporasi yang baik.

Perusahaan dalam upaya mempertahankan kelangsungan hidupnya selain dengan memperoleh laba juga harus melaksanakan segala bentuk pertanggungjawaban sosialnya. Pertanggungjawaban perusahaan terhadap lingkungan sosialnya disebut dengan Corporate Social Responsibility (CSR). Warshut (2010) mengungkapkan CSR sebagai suatuusaha atas kesungguhan perusahaan dalam menekan segala bentuk efek negatif serta meningkatkan efekpositif dari operasional perusahaan secara maksimum untuk seluruh pemangku kepentingan sehingga dapat tercapai tujuan pembangunan yang 
berkelanjutan. Dalam menerapkan kebijakan CSR, setiap perusahaan memiliki pertimbangan yang berbeda-beda.

Menurut Daniri (2008) faktor yang dapat mendorong perusahaan menjalankan CSR bisa berasaldari eksternal maupun internal perusahaan. Faktor pendorong dijalankannya CSR yang berasal dari eksternalyaitu regulasi, hukum serta kewajiban analisaatas dampak lingkungan. Audit Proper (Program penilaian peningkatan kinerja perusahaan) telah diberlakukan oleh Pemerintah melalui Kementerian Lingkungan Hidup. Faktor pendorong dijalankannya CSRyang berasal dari dalam perusahaan salah satunya yaitu perilakumanajemen serta pemilik perusahaan, selain itu tingkat pertanggungjawaban perusahaan untuk membangun masyarakat sekitar juga berpengaruh.

Setelah perusahaan melaksanakan tanggung jawab sosialnya tahap selanjutnya yang harus dilakukan perusahaan adalah melaksanakan pengungkapan tanggung jawab sosial perusahaan yang dikenaldengan sebutansocial disclosure.Social disclosure adalah sebuah proses untuk menyalurkan bagaimana dampak dari aktivitas ekonomi terhadap sosial serta lingkunganpada kelompok tertentu yang memiliki kepentingan sertapada masyarakat secara umum (Mathews, 1995).

Pengungkapan CSR dapat dilakukan perusahaan melalui bermacam-macam mediasebagai bentuk pertanggungjawaban pada para stakeholder disamping itu juga sebagai langkah dalam menjaga reputasi. Pengkomunikasian segala aktivitas maupun program CSR dianggap oleh sebagian besar perusahaan sangat penting, karena dengan begitumasyarakat semakin banyak yang mengetahui aktivitas 
RR. Maria Yulia Dwi Rengganis dan I.G.A.M Asri Dwija Putri. Pengaruh ....

social yang dijalankan perusahaan untuk kepentingan umummaka hal tersebut dapat menurunkan risiko perusahaan menerima gejolak sosial.

Melalui pengungkapan CSR, perusahaan bisa memperoleh legitimasi sosial dari masyarakat. Teori legitimasi merupakan suatu teori yang banyak digunakan untuk memperluas teori pengungkapan tanggung jawab sosialdan lingkungan (Rustiarini, 2011). Teori legitimasi munculdari adanya suatu fenomena interaksi antara masyarakat dengan organisasi yang ada disekitar lingkungannya, di mana seharusnya terdapat hubungan yang kongruen antara tujuan organisasi dengan nilai-nilai yang ada didalam masyarakat.

Legitimasi sosial menjadi hal yang sangat diinginkan perusahaan karena dengan memperolehnya maka perusahaan dapat meningkatkan kekuatan keuangannya secara maksimal untuk jangka waktu panjang melalui respon positif yang diterima perusahaan dari masyarakat dan para pelaku pasar saham. Setelah mendapatkan legitimasi sosial dari masyarakat sudah seharusnya perusahaan mempertahankannya dengan tetap menjalankan operasional perusahaan sesuai dengan norma yang ada di masyarakat dan tidak melakukan penyimpangan yang dapat mengancam keberlangsungan perusahaan.

Penelitian terkait hubungan agresivitas pajak dengan CSR sebelumnya sudah dilakukan oleh peneliti-peneliti sebelumnya. Watson (2011) mengungkapkan bahwa kegiatan CSR yang dijalankan oleh setiap entitas bisnis secara berkelanjutan dapat meminimumkan tindakan agresivitas pajak perusahaan. Selanjutnya penelitian Lanis dan Richardson (2012), hasil penelitiannya 
membuktikan bahwa nilai pengungkapan CSR yang tinggi, menggambarkan rendahnya tindakan agresivitas pajak di perusahaan tersebut.

Komisaris independen merupakan anggota dewan komisaris yang harus bersikap independen dan tidak boleh terlibat dalam segala bentuk tugas manajemen perusahaan secara langsung. Menurut Suyanto dan Supramono (2012), dengan semakin banyaknya komisaris independen yang ada dalam perusahaan maka pengawasan kinerja manajer dapat berjalan semakin efektif.Dengan banyaknya komisaris independen yang dimiliki perusahaan, kesempatan manajer untuk berlaku agresif terhadap pajak juga akan berkurang (Winata, 2014).Sehingga, tingkat agresivitas pajak perusahaan akan semakin rendah yang digambarkan dengan nilai ETR perusahaan yang tinggi.

$\mathrm{H}_{1}$ :Komisaris independen berpengaruh positif terhadap effective tax rate

Peranan sentral dalam corporate governancedipegang oleh dewan direksikarena tanggung jawab atas segala urusan dan kepentingan perusahaan diserahkan oleh hukum perseroan kepada dewan direksi(Khoirunnisa, 2015). Dewan direksi bertugas untuk mengelola manajemen perusahaan agar operasional perusahaan berjalan efektif dan efisien.

Terdapat benturan kepentingan antara perusahaan dan pemerintah. Pada umumnya perusahaan berkepentingan untuk meningkatkan laba karena dengan meningkatnya laba berarti juga bahwa kesejahteraan karyawan meningkat, sedangkan disisi lain pemerintah memandang meningkatnya laba perusahaan sebagai objek pajak. 
RR. Maria Yulia Dwi Rengganis dan I.G.A.M Asri Dwija Putri. Pengaruh ....

Kehadiran dewan direksi membawa pengaruh dalam mengurangi permasalahan teori keagenan yang biasa terjadi dalam perusahaanSam'ani (2008). Benturan kepentingan didalam perusahaan dapat dimininumkanoleh adanya dewan direksi dengan terlaksananyaprinsip-prinsip dalam GCG, maka disimpulkan semakin banyak dewan direksi dalam perusahaan akan dapat meminimumkan tindak pajak agresif yang dilakukan oleh perusahaan yang digambarkan oleh nilai ETR perusahaan yang tinggi.

$\mathrm{H}_{2}$ : Ukuran dewan direksi berpengaruh positif terhadap effective tax rate

Komite audit dalam perusahaan menjamin performa auditor akan menjadi semakin independen karena semakin sulit melakukan praktek kolusi antara manajemen dengan auditor (Watts dan Zimmerman, 1983). Jika dalam perusahaan jumlah anggota komite audit semakin banyak, maka kebijakan tax avoidance dapat dikurangi, namun apabilakeanggotaan komite audit diperusahaan lebih sedikit maka kebijakan tax avoidance akan meningkat(Winata, 2014). Dengan demikian, dapat dinyatakan komite audit dapat menekan kolusi antara manajemen dan auditor independen untuk melakukan agresivitas pajak yang digambarkan dengan nilai ETR perusahaan yang tinggi.

$\mathrm{H}_{3}$ :Komite Audit berpengaruh positif terhadapeffective tax rate

Kinerja perusahaan berkaitan erat terhadap masyarakat dan lingkungan.Perusahaan akan selalu berusaha berinteraksi secara baik dengan masyarakat sekitar dengan melaksanakan kegiatan-kegiatan sosial sebagai bentuk pertanggungjawaban sosial kepada masyarakat di lingkungannya. Perusahaan yang bersikap patuh terhadap hukum perpajakan yang ada akan memperoleh 
legitimasi dari masyarakat dan dengan demikian perusahaan akan bertahan dalam jangka waktu yang panjang karena mampu mempertahankan kedudukannya (Lanis dan Richardson, 2012).

Maesarah, dkk. (2014) menyatakan tingginya tingkat pengungkapan CSR menggambarkan bahwa perusahaan akan semakin bersikap pasif terhadap pajak. Hal tersebut karena perusahaan yang sadar akan tanggung jawab sosialnya berarti juga perusahaan memiliki kesadaran yang tinggi akan kewajibannya dalam melaksanakan kewajiban perpajakannya sehingga tingkat agresivitas akan semakin rendah yang digambarkan dengan nilai ETR perusahaan yang tinggi.

$\mathrm{H}_{4}$ : Pengungkapan Corporate Social Responsibility berpengaruh positif terhadap effective tax rate

\section{METODE PENELITIAN}

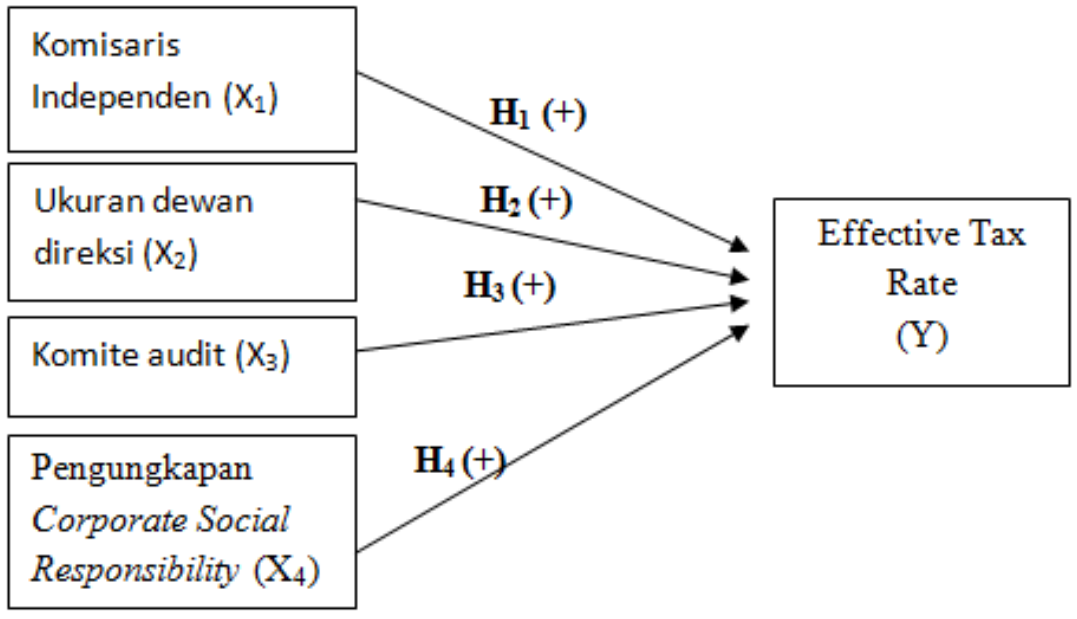

Gambar 1. Desain Penelitian

Penelitian ini dilakukan pada perusahaan yang terdaftar di BEI. Untuk mendapatkan semua data yang dibutuhkan dalam annual report dilakukan akses ke webwww.idx.co.id.ETR (Y) yang merupakan variabel dependen penelitian ini 
RR. Maria Yulia Dwi Rengganis dan I.G.A.M Asri Dwija Putri. Pengaruh ....

merupakan proksi dari agresivitas pajak. Sedangkan, variabel independennya adalahkomisaris independen $\left(\mathrm{X}_{1}\right)$, dewan direksi $\left(\mathrm{X}_{2}\right)$, komite audit $\left(\mathrm{X}_{3}\right)$, pengungkapan CSR $\left(\mathrm{X}_{4}\right)$. Jenis data menggunakan data kuantitatif berupa datadata keuangan dalam annual report.

Keseluruhan unsur yang ada di dalam obyek penelitian disebut dengan populasi, dimana populasi penelitian ini adalah perusahaan manufaktur yang terdaftar di BEItahun 2013-2015. Bagian dari populasi yang memiliki ciri-ciri tertentu dan dianggap dapat mewakili populasi secara keseluruhan disebut dengan sampel. metode non probability samplingdigunakan sebagai metode penentuan sampelnya denganpurposive samplingsebagai tekniknya.

1. Agresivitas Pajak

Agresivitas pajak diukur menggunakan proksi ETR (Y) dengan rumusnya adalah besarnya beban pajak dibagi dengan penghasilan sebelum pajak. Tingginya tingkat agresivitas pajak yang dilakukan perusahan terlihat dari nilai ETR yang rendah.Rumus ETR, yaitu:

$$
\mathrm{ETR}=\frac{\text { Beban } \text { Pajak Penghasilan }}{\text { Pendapatan } \text { sebelum pajak }}
$$

2. Komisaris independen

Perbandingan antara jumlah anggota komisaris yang bukan berasal dari internal perusahaanterhadap total dewan komisaris yang dimiliki perusahaandisebut dengan proporsikomisaris independen (Prasojo, 2011).

$$
\text { Proporsi Komisaris Independen }=\frac{\text { Jumlah Komisaris Independen }}{\text { Total Dewan Komisaris }}
$$

\section{Ukuran Dewan Direksi}


Pada umumnya kebijakan sertakualitas dari keputusan yang diambil dalam rangkameningkatkan efektivitas pencapaian tujuan organisasi tergantung pada bagaimana peran dewan direksi di perusahaan. Dalam penelitian ini ukuran dewan direksi adalah total anggota dari dewan direksi yang dimiliki perusahaan (Subramaniamet al. 2009).

\section{Komite Audit}

Untuk meningkatkan pengawasan terhadap perusahaan, dewan komisaris dibantu oleh komite audit.Berdasarkan Peraturan yang ada, di dalam perusahaan sedikitnya harus terdapat tiga 3 orang komite audit.Pada penelitian ini seluruh komite audit yang tergabung didalam perusahaan digunakan untuk mengukur variabel komite audit (Hanum dan Zulaikha, 2013).

\section{Pengungkapan Corporate Social Responsibility}

Penelitian ini untuk mengukur pengungkapan CSR menggunakan proksi CSRDI berdasarkan indikator GRI Versi 4.0 yang berjumlah 91 items. Pengukuran dilakukan dengan memberikanskorl untuk item yang diungkap didalam laporan pengungkapan CSR danskor0 diberikanterhadap item yang tidak diungkap dalam laporan pengungkapan CSR. Selanjutnya total skor pengungkapan CSRnyadengan total itempengungkapan yang diharapkan sehingga didapathasil skor pengungkapan per indikator untuk tiap perusahaan. Rumus perhitungan CSRDI adalah sebagai berikut:

$$
\mathrm{CSRDI}_{\mathrm{j}}=\frac{\sum \text { total skor item pengungkapan }}{\text { perusahaan }}
$$

Sebelum melakukan analisis regresi linier berganda, untuk menghindari terjadinya bias dalam pengujianmakadilakukanduluuji pelanggaran asumsi klasik. 
RR. Maria Yulia Dwi Rengganis dan I.G.A.M Asri Dwija Putri. Pengaruh ....

Uji yang dilakukan meliputi uji normalitas, uji autokorelasi, uji heteroskedastisitas dan uji multikolinieritas, Notasi regresi linear dinyatakan sebagai berikut:

$$
Y=\alpha_{0+} \beta_{1} X_{1}+\beta_{2} X_{2}+\beta_{3} X_{3}+\beta_{4} X_{4}+\varepsilon
$$

Keterangan:

Y= ETR yang merupakan proksi dari Agresivitas Pajak

$\alpha_{0}=$ Konstanta

$\beta_{1}-\beta_{5}=$ Koefisien regresi

$\mathrm{X}_{1}=$ Komisaris independen

$\mathrm{X}_{2}=$ Ukuran dewan direksi

$\mathrm{X}_{3}=$ Komite audit

$\mathrm{X}_{4}=$ Pengungkapan item CSR perusahaan

$\varepsilon=$ error

Koefisien determinan $\left(\mathrm{R}^{2}\right)$ menunjukkan besarnya kemampuan variabelvariabel bebas menjelaskan varians dari variabel terikatnya (Ghozali, 2009).Apabila dalam penelitian diperoleh nilai $\mathrm{R}^{2}$ yang kecil artinya secara keseluruhan terdapat keterbatasan kemampuan variabel independen dalam menjelaskan variabel dependennya.

Kelayakan model regresi dalam penelitian diuji dengan statistik $\mathrm{F}$. Penelitian ini menggunakan $\mathrm{P}_{\text {value }} 5 \%$, dengan kriteria pengujian apabila nilai $\mathrm{P}_{\text {value }} \mathrm{F}<5 \%$, maka koefisien regresi layak digunakan.Pengaruh variabel independen secara parsial dalam menjelaskan variasi variabel dependennya dapat diuji dengan uji statistik t.Penelitian ini menggunakan tingkat $\mathrm{P}_{\text {value }} 5 \%$, dengan kriteria pengujian apabila nilai $\mathrm{P}_{\text {value }}<5 \%$ berarti terdapat pengaruh variabel independen. 


\section{HASIL DAN PEMBAHASAN}

Proses penyeleksian populasi untuk menjadi sampel dalam penelitian ini menggunakan teknik purposive sampling dimana proses penyeleksiannya adalah sebagai berikut:

Tabel 2.

\section{Hasil Penyeleksian Sampel}

\begin{tabular}{clc}
\hline No. & \multicolumn{1}{c}{ Keterangan } & Jumlah \\
\hline 1 & $\begin{array}{l}\text { Perusahaan ManufakturyangterdaftardiBEIselama periode 2013- } \\
2015 .\end{array}$ & 154 \\
2 & $\begin{array}{l}\text { Perusahaan yang tidak mempublikasikan annual report secara } \\
\text { berturut-turut pada periode pengamatan }\end{array}$ & $(17)$ \\
3 & $\begin{array}{l}\text { Perusahaan yang tidak menyajikan laporan pengungkapan CSR } \\
\text { dalamannual report }\end{array}$ & $(47)$ \\
4 & $\begin{array}{l}\text { Perusahaan yang mendapat kerugian padatahunamatan } \\
5\end{array}$ & $\begin{array}{l}\text { Perusahaan yang tidak menyajikan annual report dalam mata } \\
\text { uang rupiah }\end{array}$ \\
& Sampel & $\mathbf{3 3}$ \\
\hline & Jumlah pengamatan (33 perusahaan $\times \mathbf{3}$ tahun)
\end{tabular}

Uji Kolmogorov-Smirnovdigunakan sebagai alat uji normalitas, dimana data dinyatakan normal apabila $P_{\text {value }}(2$-tailed $)>0,05$. Hasil uji menunjukkan

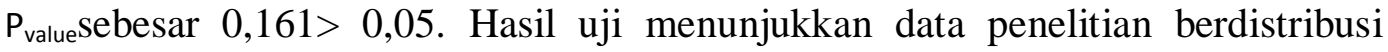
normal. 
Tabel 3.

Hasil Uji Multikolinieritas

\begin{tabular}{clrr}
\hline No. & Keterangan & Nilai Tolerance & Nilai VIF \\
\hline \multirow{2}{*}{1} & Komisaris independen & 0,906 & 1,104 \\
2 & Dewan direksi & 0,829 & 1,206 \\
3 & Komite audit & 0,975 & 1,025 \\
4 & Pengungkapan CSR & 0,927 & 1,079 \\
\hline Sumber: & Data diolah, 2016
\end{tabular}

Tabel 3. memperlihatkan bahwa setiap variabel bebas memiliki nilai tolerance $>0,10$ sertamemiliki nilai $\mathrm{VIF}<10$. Hasil tersebut menunjukkan model regresi penelitian ini terbebas dari multikolinieritas.

Tabel 4.

Hasil Uji Autokorelasi

\begin{tabular}{cccccc}
\hline Model & $\mathbf{R}$ & $\mathbf{R}^{2}$ & $\begin{array}{c}\text { Adjusted } \\
\mathbf{R}^{2}\end{array}$ & $\begin{array}{c}\text { Std. Error of } \\
\text { the Estimate }\end{array}$ & DW \\
\hline 1 & ,392a &, 154 &, 117 &, 040567 & 1,429 \\
\hline Sumber: Data diolah, 2016 & & & &
\end{tabular}

Tabel 4. menunjukkan nilai DW sebesar 1,429 berada diantara -2 dan +2 , maka kesimpulannya bahwa model yang digunakan terbebas dari gejala autokorelasi.

Tabel 5. Hasil Uji Heteroskedastisitas

\begin{tabular}{clc}
\hline NO & \multicolumn{1}{c}{ Variabel } & Sig. \\
\hline 1 & Komisaris Independen & 0,336 \\
2 & Dewan Direksi & 0,357 \\
3 & Komite Audit & 0,077 \\
4 & Pengungkapan CSR & 0,573 \\
\hline
\end{tabular}

Sumber: Data diolah, 2016 
Tabel 5. Memperlihatkanbahwa seluruh variabel independen nilai signifikansinya> 0,05 maka kesimpulannya adalah data penelitian ini terbebas dari heteroskedastisitas.

Tabel 6.

Ringkasan Hasil Uji Statistik

\begin{tabular}{|c|c|c|c|c|c|}
\hline Variabel & B & $\begin{array}{l}\text { Std. } \\
\text { Error }\end{array}$ & Beta & $\mathbf{T}$ & Sig \\
\hline (Constant) & ,235 & 031 & & 7,655 & ,000 \\
\hline $\mathrm{KI}$ &,- 052 & 039 &,- 132 & $-1,321$ & , 190 \\
\hline DD &,- 001 &, 002 &,- 029 &,- 276 & ,783 \\
\hline KA &,- 001 & ,008 &,- 007 &,- 073 & ,942 \\
\hline CSR & 248 & ,064 & ,383 & 3,884 &, 000 \\
\hline $\mathrm{R}^{2}$ & 0,154 & & & & \\
\hline F hitung & 4,262 & & & & \\
\hline Signifikansi F & 0,003 & & & & \\
\hline
\end{tabular}

$\mathrm{ETR}=0,235-0,052 \mathrm{KI}-0,001 \mathrm{DD}-0,001 \mathrm{KA}+0,248 \mathrm{CSR}+\varepsilon$

Nilai konstanta sebesar 0,235 menunjukkan jika komisaris independen $\left(\mathrm{X}_{1}\right)$, dewan direksi $\left(\mathrm{X}_{2}\right)$, komite audit $\left(\mathrm{X}_{3}\right)$, dan pengungkapan CSR $\left(\mathrm{X}_{4}\right)$ adalah 0, maka nilai ETR (Y) adalah sebesar 0,235. Nilai koefisien $\beta 1=-0,052$ memiliki arti bahwa jika nilai komisaris independen $\left(\mathrm{X}_{1}\right)$ naik sebanyak 1 satuan, nilai ETR (Y) akan turun sebanyak 0,052 satuan dengan berasumsi bahwa variabel lainnya tidak berubah.Nilai koefisien $\beta 2=-0,001$ memiliki arti bahwa jika nilai dewan direksi $\left(\mathrm{X}_{2}\right)$ naik 1 satuan, maka nilai ETR (Y) akan turun sebanyak 0,001 satuan dengan berasumsi bahwa variabel lainnya konstan. Nilai koefisien $\beta 3=-0,001$ memiliki arti bahwa jika nilai komite audit $\left(\mathrm{X}_{3}\right)$ naik 1 satuan, maka nilai ETR (Y) akan turun sebanyak 0,001 satuan dengan berasumsi bahwa variabel lainnyakonstan.Nilai koefisien $\beta 4=0,248$ memiliki arti bahwa jika nilai pengungkapan CSR $\left(\mathrm{X}_{4}\right)$ naik 1 satuan, maka nilai ETR (Y) akan naik sebanyak 0,248 satuan denganberasumsi variabel lainnya tidak berubah. 
RR. Maria Yulia Dwi Rengganis dan I.G.A.M Asri Dwija Putri. Pengaruh ....

Nilai $\mathrm{R}^{2}$ berguna untuk menunjukkan besarnya kemampuan variabel independen dalam menjelaskan variabel dependennya. Pada tabel 6.terlihat besarnya nilai $\mathrm{R}^{2}$ adalah sebesar 0,154 memiliki arti bahwa 15,4 persennilai ETR sebagai proksi dari agresivitas pajak dipengaruhi oleh variabel independen yang digunakan dalam penelitian ini. Namun, sebanyak 84,6 persen agresivitas pajak yang diproksikan dengan ETR dipengaruhi oleh variabel-variabel lain yang tidak digunakan pada penelitian ini. Dalam menguji kelayakan suatu model regresi digunakan uji statistik F. PadaTabel 6.terlihat hasil perhitungan F menunjukkan angka 4,262 dan tingkat signifikansinya sebesar $0,003<\alpha=0,05$. Hasil tersebut menunjukkan model regresi dalam penelitian ini layak digunakan.

Hasil pengujian padaTabel 6. Menunjukkan variabel komisaris independen tidak berpengaruh terhadap nilai ETR, dengan tingkat signifikansinya 0,190> 0,05. Oleh karena komisaris independen tidak berpengaruh terhadap nilai effective tax rate yang merupakan proksi dari agresivitas pajak, maka dapat dinyatakan bahwa banyak atau sedikitnya anggota komisaris independen yang dimiliki perusahaan tidak ada pengaruhnyapada tindak agresivitas pajak perusahaan.

Kebijakan perusahaan dalam menentukan berapa banyak komisaris independen dalam perusahaannya berbeda-beda. Berkaitan dengan hasil tidak signifikan yang diperoleh dalam penelitian ini dimungkinkan karena sebagian besar keputusan perusahaan untuk menempatkan atau menambah anggota dewan komisaris independen merupakan bagian dari kepatuhan perusahaan padaperaturan yang ada. Peraturan tersebut mengatur bahwa setiap perusahaan setidaknya harus memiliki 30\% anggota komisaris independen dari total anggota 
dewan komisaris secara keseluruhan yang ada dalam perusahaan. Sehingga dapat dinyatakan bahwa jumlah anggota komisaris independen yang dimiliki perusahaanbelum efektif untuk dijadikanmedia untuk mencegah maupun mengurangi tindakan penghindaran pajak.Penelitian sebelumnya oleh Pradipta dan Supriyadi (2015) juga memperoleh hasil yang serupa dimana proporsi komisaris independen tidak berpengaruh pada agresivitas pajak.

Hasil pengujian pada Tabel 6. menunjukkan variabel dewan direksi tidak berpengaruh terhadap nilai ETR, dengan tingkat signifikansinya 0,783>0,05.Oleh karena dewan direksi tidak berpengaruh terhadap nilai effective tax rate yang merupakan proksi dari agresivitas pajak, maka dapat dinyatakan bahwa sedikit banyaknya anggota dewan direksiyang dimiliki perusahaan tidak ada pengaruhnya terhadap tindakan agresivitas pajak.

Tidak signifikannya hasil yang diperoleh dalam penelitian ini dimungkinkan karena dampak yang akan ditanggung perusahaan setelah melakukan tindak agresivitas pajak jauh lebih besar dan menjadi pertimbangan penting bagi perusahaan. Beberapa dampak yang akan diterima oleh perusahaan akibat melakukan agresivitas yaitu sanksi yang akan didapatkan dari petugas pajak, menurunnya harga saham perusahaan, atau bisa juga reputasi yang dibangun perusahaan selama ini menjadi kurang baik akibat audit dari petugas pajak. Hal inilah yang lebih berpengaruh terhadap pengambilan keputusan pihak manajemen dalam masalah kebijakan perpajakannya daripada melihat keberadaan atau banyaknya anggota dewan direksi pada perusahaan. 
RR. Maria Yulia Dwi Rengganis dan I.G.A.M Asri Dwija Putri. Pengaruh ....

Faktor yang mempengaruhi keputusan perusahaan dalam membuat kebijakan perpajakannya tidak ditentukan dari jumlah dewan direksi pada perusahaan, sehingga kesimpulannya efektivitas mekanisme pengendalian aktivitas agresivitas pajak lebih berkaitan pada norma, kepercayaan dan nilai yang diterima dalam suatu perusahaan. Penelitian sebelumnya oleh Khoirunnisa (2015) juga menemukan hasil yang sama dimanavariabel dewan direksi tidak berpengaruh terhadap agresivitas pajak.

Tabel 6. Menunjukkan hasil uji statistik variabel komite audit terhadap nilai ETR, dengan tingkat $P_{\text {value }}$ 0,942>0,05. Hasil uji variabel komite audit terhadap nilai effective tax rate yang merupakan proksi dari agresivitas pajak menunjukkan bahwa sedikit banyaknyajumlahkomite audit tidak ada pengaruhnya terhadap tindakan pajak agresif. Hasil tidak signifikan yang diperoleh dalam penelitian ini memberi bukti bahwa banyak sedikitnya anggota komite audit perusahaan tidak bisamenjamin intervensi dapat dilakukan dalam menentukan kebijakan besarnya tarif pajak efektif perusahaan. Hal tersebut sejalan dengan penelitian Puspita (2014) yang menemukan bahwa jumlah komite audit dalam sebuah perusahaan tidak ada pengaruhnya terhadap tindakan agresivitas pajakyang dilakukan oleh suatu perusahaan.

Tidak berpengaruhnya komite audit terhadap tingkat agresivitas pajak perusahaan mungkin karena kecenderungan perusahaan melakukan tindakan agresivitas pajak bukan tergantung dari banyaknya anggota komite audit yang tergabung tetapi lebih kepada bagaimana kualitas serta independensi dari anggota komite audit tersebut untuk menganalisa apakah tindakan penghindaran pajak 
tersebut dilakukan oleh perusahaan atau tidak. Selain itu, ada kemungkinan bahwa penambahan anggota komite audit dalam perusahaan hanya dimaksudkan untuk memenuhi kepatuhan atas peraturan yang ada dimana diharuskan sedikitnya terdapat 3 (tiga) orang anggota komite audit dalam suatu perusahaan.

Tabel 6.Juga memperlihatkan adanya pengaruh positif darivariabel pengungkapan CSR pada nilai ETR, dengantingkat $P_{\text {value }} 0,000<$ 0,05.Tingginyanilai pengungkapan CSR perusahaan diikuti dengan nilai ETR yang meningkat yang menggambarkan bahwa tingkat agresivitas pajak perusahaan semakin rendah.

Hasil yang diperoleh dalam penelitian ini berarti bila pengungkapan CSR perusahaan tinggi, akan diikuti dengan rendahnya tingkat agresivitas pajak perusahaan.Setiap kegiatan CSR yang dijalankan oleh perusahaan itu merupakan sebuah kegiatan yang tidak hanya berfokus untuk tujuan ekonomi tetapi lebih menitik beratkan pada bidang sosial dan lingkungan. Bagaimana dampak yang akan diterima masyarakat setelah kegiatan sosial tersebut dijalankan, karena perusahaan melaksanakan kegiatan-kegiatan sosial tersebut juga sebagai bentuk tanggung jawabnya padastakeholdernya.

Perusahaan yang memiliki peringkat rendah untuk pengungkapan CSRnya dianggap kurang memiliki tanggung jawab sosial sehingga dalam menjalankan tanggungjawabnya bidang perpajakan, jugacenderungakanlebih bersikap agresif (Hoi et al, 2013). Sedangkan, perusahaan yang memiliki peringkat tinggi dalam pengungkapan CSRnya dipandang lebih peduli terhadap lingkungan sosial serta tidak sekedar mementingkan hak-hak investor tetapi perhatiannya jugabesar akan 
RR. Maria Yulia Dwi Rengganis dan I.G.A.M Asri Dwija Putri. Pengaruh ....

hak-hak publik, sehingga perusahaan cenderung memiliki kesadaran yang tinggi terhadap kewajiban perpajakannya. Penelitian ini menunjukkan hasil yang sejalan dengan penelitian sebelumnya dimana semakin banyak perusahaan mengungkapkan kegiatan CSR perusahaannya makatingkat penghindaran pajaknya semakin rendah (Yoehana, 2013).

\section{SIMPULAN}

Simpulan penelitian ini yaitubahwa mekanisme Corporate Governanceyang diukur dengan variabel komisaris independen, dewan direksi dan komite audit tidak berpengaruh terhadap effective tax rate. Sedangkan yang berpengaruh terhadap nilai effective tax ratedalam penelitian ini adalah variabel Pengungkapan CSR, dimana penelitian ini membuktikan adanya pengaruh negatif dari pengungkapan CSR terhadap nilai effective tax rate.

Saran dan rekomendasi yang dapat diberikan oleh peneliti adalah oleh karena hasil $\mathrm{R}^{2}$ yang diperoleh dalam penelitian ini tergolong rendah yaitu 0,154 atau $15,4 \%$. Hasil tersebut artinya pengaruh dari variabel independen yang digunakan dalam penelitian hanya $15,4 \%$ terhadap ETR yang merupakan variabel dependen dalam penelitian ini. Sedangkan, 84,6\% dipengaruhi oleh variabel lain. Peneliti selanjutnya yang mengambil topik serupa diharapkan dapat meneliti variabel lain yang dapat menganalisis adanya tindakan agresivitas pajak seperti variabel kepemilikan institusional serta kualitas audit.

Dalam penelitian ini Pengukuran untuk Corporate Sosial Responsibility dengan metode checklist memiliki kelemahan subyektifitas peneliti, oleh karena itu untuk peneliti selanjutnya dapat menggunakan metode lain seperti observasi 
dan wawancara langsung dengan perusahaan sampel terkait implementasi Corporate Sosial responsibilty.Untuk regulator dan standard setter dapat membuat standar pengungkapan tanggung jawab sosial yang lebih terperinci, mengenai hal-hal yang harus diungkapkan sehingga nantinyaterdapat kesamaan persepsi perusahaan dalam melakukan pengungkapan tanggung jawab sosialnya.

\section{REFERENSI}

Balakrishnan, K., J. Blouin, and W, Guay. 2011. "Does Tax Aggressiveness Reduce Financial Reporting Transparency?".www.google.co.id. Diakses tanggal 14 September 2016.

Daniri, Mas Achmad. 2008. Standardisasi Tanggung jawab Sosial Perusahaan. http://www.madani-ri.com/. Diakses tanggal 28 Oktober 2016.

Darmadi, Iqbal Nul Hakim(2013). Analisis Faktor-faktor yang mempengaruhi manajmen pajak dengan indikator Tarif Pajak Efektif. Skripsi FEB Undip

Eviati, Lisa. 2013. Dampak Implementasi Corporate Social Responsibility Terhadap Agresivitas Pajak, Slide Presentasi Sidang.

Frank, M., Lynch, L., dan Rego, S. 2009.Tax Reporting Aggressiveness and Its Relation to Aggressive Financial Reporting.The Accounting Revie, 84, 467496.

Ghozali, Imam. 2009. Analisis Multivariate Lanjutan dengan Program SPSS. Semarang: Badan Penerbit Universitas Diponegoro.

Hanum, H. R., \& Zulaikha. 2013. Pengaruh Karakteristik Corporate Governance terhadap Effective Tax Rate (Studi Empiris pada BUMN yang Terdaftar di BEI 2009 - 2011). ISSN, 2, 1 - 10.

Hoi, Chun-Keung (Stan), Wu, Qiang, \& Zhang, Hao. (2013). Is Corporate Social Responsibility (CSR) Associated with Tax Avoidance? Evidence from Irresponsible CSR Activities.The Accounting Review, 88(6), 2025-2059.

Jimenez, E. \& Patrinos, H.A. (2008). Can Cost-Benefit Analysis Guide Education Policy in Developing Countries. The World Bank, Human Development, Network Education Team. 
Kamila, Putri Almainda dan Dwi Martani. 2013. Analisis Hubungan Agresivitas Pelaporan Keuangan dan Agresivitas Pajak.Universitas Indonesia.Jurnal Simposium NasionalAkuntansi XVII.Lombok.

Karayan, John E. dan Charles W. Swenson (2007).Strategic Business Tax Planning. New Jersey: John Wiley \& Son.

Khoirunnisa. 2015. Pengaruh Corporate Governance terhadap Tax Avoidance pada Perusahaan Manufaktur yang terdaftar di Bursa Efek Indonesia. Universitas Lampung

Kurniasih, Tommy dan Sari Maria M. Ratna. 2013. "Pengaruh Return On Assets, Leverage, Corporate Governance, Ukuran Perusahaan dan Kompensasi Rugi Fiskal Pada Tax Avoidance". Buletin Studi Ekonomi Vol.18

Lanis, R. and G. Richardson. 2012. "Corporate Social Responsibility and Tax Aggressiveness: An Empirical Analysis”. J. Account. Public Policy, pp.86108.

Maesarah, Yasti, Atikah, Siti dan Husnaini, Wahidatul. 2014. "Pengaruh Karakteristik Perusahaan dan Corporate Social Responsibillity Terhadap Penghindaran Pajak.” Simposium Nasional Akuntansi XVI. Pontianak.

Mathews, M.R (1995). "Social and Environmental Accounting: A Practical Demonstration of Ethical Concern", Journal of Business Ethics, Vol. 14, pp 663-671.

Ngadiman, dan Puspitasari, C. (2014). Pengaruh Leverage, Kepemilikan Institusional, dan Ukuran Perusahaan terhadap Penghindaran Pajak (Tax Avoidance) pada Perusahaan Sektor Manufaktur yang Terdaftar di Bursa Efek Indonesia 2010-2012. Jurnal Akuntansi, 18(3):408- 421.

Pohan, hotman tohir. 2008. Pengaruh corporate governace, rasio tobin q, perata laba terhadap penghindaran pajak pada perusahaan publik. Fakultas ekonomi, universitas trisakti.

Pradipta, Dyah Hay., dan Supriyadi. 2015. Pengaruh Corporate Social Responsibility (CSR), Profitabilitas, Leverage, Dan Komisaris Independen Terhadap Praktik Penghindaran Pajak. Simposium Nasional Akuntansi XVIII. Medan,16-19 September

Puspita, Silvia Ratih. 2014. "Pengaruh Tata Kelola Perusahaan terhadap Penghindaran Pajak". Diponegoro Journal of Accounting,3(2):1-13. 
Putranti, Anissa S dan Yulia Setiawanta. (2015). Pengaruh Kepemilikan Institusional, Struktur Dewan Komisaris, Kualitas Audit Dan Komite Audit Terhadap Tax Avoidance. Semarang: Universitas Dian Nuswantoro.

Rego, S. 2003. Tax Avoidance Activities of U.S. Multinational Corporations. Contemporary Accounting Research, 20, 805-833.

Rustiarini.2011. Pengaruh Struktur Kepemilikan Saham pada Pengkukapan Corporate Social Responsibility. AUDI Jurnal Akuntansi dan Bisnis, 6(1): 104-119.

Rusydi, M. Khoiru. 2013. Pengaruh Ukuran Perusahaan Terhadap Aggressive Tax Avoidance Di Indonesia.Jurnal Akuntansi Multiparadigma, 4(2):322-329

Sam'ani. 2008. Pengaruh Good Corporate Governance dan Leverage terhadap Kinerja Keuangan pada Perbankan yang Terdaftar di Bursa Efek Indonesia (BEI) Tahun 2004 - 2007. Semarang: Universitas Diponegoro.

Sari, D. K., Martani, D. 2010.Karakteristik Kepemilikan Perusahaan, Corporate Governance, dan Tindakan Pajak Agresif.Simposium Nasional Akuntansi XIII Purwokerto 2010.

Sartori, Nicola. 2010. Effect of Strategic Tax Behaviors on Corporate Governance. www.ssrn.com

Sunyoto, Danang. 2016. Metodeologi Penelitian Akuntansi. PT Refika Aditama: Bandung

Suwito, Edy dan Arleen Herawaty. 2005. "Analisis Pengaruh Karakteristik Perusahaan Terhadap Tindakan Perataan Laba Yang Dilakukan Oleh Perusahaan Yang Terdaftar di Bursa Efek Jakarta”. Simposium Nasional Akuntansi VIII Solo.hal. 136-146

Suyanto, K. D., dan Supramono. 2012. Likuiditas, Leverage, Komisaris Independen, dan Manajemen Laba Terhadap Agresivitas Pajak Perusahaan. Jurnal Keuangan dan Perbankan Mei 2012, 16(2):167-177.

Warhust, Alyson. 2010. Kewajiban CSR sebagai Instrumen Pemotongan Pajak.http://www.hukumonline.com/berita/kewajiban-CSRsebagaiinstrumenpemotongan-pajak. Diakses 15 September 2016.

Watson, Luke. 2011. Corporate Social Responsibility and Tax Aggressiveness: An Examination of Unrecognized Tax Benefits. American Taxation Association Midyear Meeting Paper: New Faculty/Doctoral Student Research Session. 
RR. Maria Yulia Dwi Rengganis dan I.G.A.M Asri Dwija Putri. Pengaruh ....

Watts, Ross L. dan Jerold L. Zimmerman. 1983. Agency Problems, Auditing and The Theory of The Firm : Some Evidence, Journal of Law and Economics, 26(3): 613- 633.

Winarsih, Rina., Prasetyono., Kusufi, Muhammad Syam. 2014. Pengaruh Good Corporate Governance dan Corporate Sosial Responsibility Terhadap Tindakan Pajak Agresif (Studi Pada Perusahaan Manufaktur Yang Listing di Bei Tahun 2009-2012).

Winata, Fenny.2014. Pengaruh Corporate Governance Terhadap Tax Avoidance pada Perusahaan yang Terdaftar di Bursa Efek Indonesi Tahun 2013.'Tax and Accounting Review, 4(1).

Yoehana, Maretta. 2013. "Analisis Pengaruh Corporate Social Responsibility Terhadap Agresivitas Pajak.Diponegoro Journal Of Accounting 